\title{
Analisis teori kritis Jurgen Habermas: Agama dan kehidupan modern mahasiswa ibu kota Jakarta
}

\author{
Adinda Novalia R Putri, Luhung Achmad Perguna* \\ Universitas Negeri Malang, Jl. Semarang No. 5 Malang, Jawa Timur, Indonesia \\ *Penulis korespondensi, Surel: luhung.fis@um.ac.id
}

Paper received: 03-02-2021; revised: 15-02-2021; accepted: 28-02-2021

\begin{abstract}
Abstrak
Ibu Kota Indonesia, Jakarta, menjadi tempat strategis bagi arus globalisasi untuk membuka keran selebar-lebarnya. Globalisasi yang menjadikan budaya barat sebagai acuan gaya hidup ini kemudian melahirkan modernisasi. Modernisasi merupakan sebuah wujud transformasi kondisi yang sebelumnya kurang maju, menjadi berkembang ke sebuah kemajuan yang lebih baik. Segala pusat kehidupan cenderung didominasi pada kota Jakarta. Modernisasi yang terus memaparkan pengaruhnya ini kemudian memberi dampak kepada masyarakatnya juga, seperti berkembangnya paham hedonisme dan individualisme yang bertentanngan dengan ajaran agama. Agama sendiri merupakan sarana media penghubung antara manusia dan Tuhan. Kehidupan modern yang dijalani oleh mahasiswa di Jakarta ini mau tidak mau akan berdampak kepada cara atau pemahaman seseorang pada suatu hal termasuk agama. Setiap orang memiliki perspektif tersendiri akan suatu hal. Cara pandang mahasiswa dalam memandang partik agamanya pun sangat bervariasi dan memiliki latar belakangnya sendiri. Dalam penelitian ini banyak ditemukan jawaban dan temuan unik mengenai agama di dalam kehidupan mahasiswa Jakarta ini, serta pendapatnya mengenai agama di tengah-tengah kehidupan modern.
\end{abstract}

Kata kunci: agama; kehidupan modern; mahasiswa; Jakarta.

\section{Pendahuluan}

Sebagai ibu kota, Jakarta merupakan kota strategis bagi globalisasi untuk menjalankan prinsipnya. Globalisasi berawal dari kondisi dunia yang kian hari kian menyatu akibat kemajuan teknologi komunikasi global. Sebuah fakta yang tidak asing untuk didengar bahwa seluruh batas-batas nasional dapat ditembus melalui kemudahan berkomunikasi dan bertukar informasi. Munculnya fenomena globalisasi ini juga menimbulkan persoalan baru, seperti masuknya nilai-nilai kebudayaan barat di Indonesia yang banyak diserap oleh anak muda kita khususnya di Jakarta dan terjadinya modernisasi. Modernisasi merupakan suatu kondisi masyarakat dimana pada tahapan ini, masyarakat mulai bertransformasi ke arah kehidupan yang lebih baik dan maju, dengan harapan bahwa kesejahteraan hidupnya bisa terjamin (Hesti, 2018). Masuknya arus globalisasi yang menghasilkan modernisasi ini tidak dapat dihindari, karena semua negara pasti juga membutuhkan akses teknologi komunikasi yang mudah untuk kelancaran keperluan ekonomi-sosial suatu negara. Maka, tidak bisa dipungkiri pula jika masyarakat di dunia juga mau tidak mau terkena dampak dari globalisasi tersebut.

Salah satu akibat dari munculnya sebuah peradaban kehidupan modern adalah sifat manusia yang semakin berani dan tidak berhenti menanyakan serta mengkritisi segala hal, mulai dari hal sederhana seperti bagaimana bisa terjadi hujan, sampai hal besar seperti eksistensi Tuhan. Kehidupan yang telah termodernisasi cenderung menjadikan kita menjadi pribadi yang selalu berpikir logis, menginginkan segala hal secara instan, serta mementingkan diri sendiri. Salah satu hasil dari modernisasi ini adalah lahirnya paham hedonisme dan individualisme. Didukung oleh kemudahan manusia dalam mengakses konten-konten di sosial 
media, di Indonesia sudah banyak ditemukan praktik kedua paham ini yang semakin menjamur, contohnya seperti kebiasaan menghamburkan duit untuk bersenang-senang (pergi ke club, belanja barang mewah, dan sebagainya), interaksi warga di suatu perumahan yang semakin jarang, persaingan di dunia kerja, mengecilnya lingkar pertemanan, dan sebagainya. Namun, di sisi lain, Indonesia adalah negara yang kental dengan unsur agama dan budaya. Bisa dilihat dari sudut pandang agama bahwa paham hedonisme dan indivdualisme sendiri sangat bertabrakan dengan apa yang agama telah ajarkan. Contohnya menurut agama Islam, sebagai agama dengan pemeluk terbanyak di Indonesia, bahwa telah tertulis dalam QS. Al-Hadid [57]:20, yaitu:

"Ketahuilah, bahwa sesungguhnya kehidupan dunia ini hanyalah permainan dan sesuatu yang melalaikan, perhiasan dan bermegah-megah antara kamu serta berbangga-banggaan tentang banyaknya harta dan anak, seperti hujan yang tanam-tanamannya menganggumkan para petani; kemudian tanaman itu menjadi kering dan kamu lihat warnanya kuning kemudian menjadi hancur. Dan akhirat nanti ada azab yang keras dan ampunan dari Allah serta keridhaan-Nya. Dan kehidupan dunia ini tidak lain hanyalah kesenangan yang menipu."

Apa yang tertulis dalam hadist tersebut menunjukkan sifat agama yang jauh dari hal duniawi. Agama secara terang-terangan menentang gaya hidup di dunia yang serba mewah dan tidak memikirkan kehidupan di akhirat nanti. Sementara itu, telah tertulis dalam QS. Luqman ayat 18:2 bahwa,

"Dan janganlah kamu memalingkan mukamu dari manusia (karena sombong) dan janganlah kamu berjalan di muka bumi dengan angkuh. Sesungguhnya Allah tidak menyukai orangorang yang sombong lagi membanggakan."

Hadist ini secara gamblang memperlihatkan pertentangan agama terhadap gaya hidup individualisme, yaitu saat manusia hanya mementingkan dirinya sendri. Banyak ditemukan di masyarakat Indonesia mengenai praktik dari paham ini, seperti sudah tidak asing lagi bagi kita melihat perumahan di perkotaan yang begitu sepi, bahkan masing-masing penghuni belum tentu mengenal satu sama lain. Begitu pula persaingan di dunia kerja yang begitu ketat, sehingga mayoritas manusianya tidak ragu lagi bila harus mementingkan dirinya sendiri tanpa memikirkan nasib kerabat kerjanya. Adapun, dalam agama Kristen juga tertulis mengenai pertentangan terhadap hedonisme dan individualisme, seperti yang tertulis pada Galatia 5:1618:

"Maksudku ialah: hiduplah oleh Roh, maka kamu tidak akan menuruti keinginan daging. Sebab keinginan daging berlawanan dengan keinginan Roh dan keinginan Roh berlawanan dengan keinginan daging - karena keduanya bertentangan — sehingga kamu setiap kali tidak melakukan apa yang kamu kehendaki. Akan tetapi jikalau kamu memberi dirimu dipimpin oleh Roh, maka kamu tidak akan hidup di bawah hukum Taurat."

Maksud dari keinginan daging dalam ayat di atas adalah analogi dari kehidupan duniawi, sementara Roh adalah hal surgawi. Jelas bahwa ayat tersebut menyebutkan pertentangan terhadap hedonism dan individualisme, karena kedua paham tersebut merupakan paham mengenai hal duniawi semata. Masing-masing agama memiliki cara penyampaiannya sendiri, namun dapat disimpulkan oleh penulis bahwa kutipan beberapa ayat di atas menunjukkan bahwa agama menentang paham hedonisme dan individualisme. 
Sebelum ditulisnya penelitian ini, penulis telah melakukan literasi terhadap beberapa penelitan terdahulu yang berkaitan dengan topik yang penulis angkat dan menjadi acuan dalam penulisan penelitian ini. Salah satunya adalah yang ditulis oleh Bhanu Viktorhadi (2017) dengan judul Kritik Jurgen Habermas Terhadap Peran dan Fungsi Agama dalam Masyarakat Modern. Penelitian ini mengkaji mengenai seperti apa peran dan fungsi agama di tengah masyarakat modern saat ini, yang tentunya tidak sama lagi seperti di abad pertengahan, dan mengenai bagaimana sikap/tindakan agama menghadapi peradaban dunia modern. Penelitian ini kemduian dikaji menggunakan teori kritis Jurgen Habermas, yang kemudian menarik sebuah kesimpulan bahwa agama harus melakukan gerakan perubahan dalam penyampaian ajarannya yaitu dengan menyesuaikan dengan kondisi masyarakat kita sekarang ini, supaya tercipta sebuah komunikasi yang sehat antara kedua belah pihak, yang nantinya mempertemukan keduanya di kondisi hubungan yang baik. Perbedaan penulisan terletak pada kebaharuan subjek penelitian, yaitu mahasiswa yang berdomisili di Jakarta serta sedang menempuh perguruan tinggi di daerah Jakarta dan spesifikasi bahasan penelitian oleh penulis terhadap paham hedonisme dan individualisme yang lahir akibat masuknya modernisasi di Indonesia. Topik yang telah penulis angkat ini kemudian dianalisis menggunakan teori kritis yang dicetuskan Jurgen Habermas.

Habermas menganggap bahwa masyarakat modern saat ini terlalu berorientasi pada rasionalitas instrumental, yaitu rasionalitas yang cenderung mengarah kepada penggunaannya saja (Viktorahadi, 2017). Habermas melihat bahwa rasionalitas instrumental menimbulkan suatu masyarakat dengan kesadaran yang berlandaskan teknologi dan teknokrat/kepemerintahan. Munculnya masyarakat dengan kesadaran tersebut dibagi menjadi dua tahap, yaitu, 1) tahap teori sosial, dimana manusia yang cenderung berpikir teknoktratis dapat mengancam dimensi relfektif dalam kehidupan manusia, dan 2) tahap teori pengetahuan, dimana rasionalitas ini menguasai pemikiran masyarakat modern.

Habermas memandang adanya tanda-tanda kemunduran kemampuan reflektif dalam diri manusia. Tanpa upaya reflektif, manusia bisa kehilangan makna atas hidup. Berdasarkan hal ini, Habermas ingin mencetuskan sebuah paradigma baru, yaitu etik komunikatif yang lebih universal agar manusia dapat mencapai titik rasionalitas yang lebih komunikatif. Disinilah diperlukan teori kritik Habermas terhadap agama kontemporer masa kini. Di zaman yang semakin modern, muncul permasalahan baru yang lebih kompleks pula. Segala kritik, pertimbangan, serta pemikiran diperlukan oleh sebuah ajaran agama untuk menemukan kebenaran dan kesepahaman. Teori kritis berguna sebagai mediasi agama dalam berbahasa dan menyampaikan ajarannya dalam cara yang lebih mudah dimengerti oleh manusia-manusia di zaman ini.

Berdasarkan kondisi masyarakat modern yang telah dijabarkan sebelumnya, topik yang penulis angkat ini akhirnya mengarah pada tiga batasan permasalahan, yaitu 1) Dimana letak agama dalam kehidupan menurut mahasiswa di ibu kota?; 2) Apakah agama masih dapat berdampingan dengan kehidupan modern yang begitu cepat dan kompleks?; dan 3) Bagaimana peran agama sebagai penyeimbang kehidupan modern yang kental dengan unsur individualisme dan hedonisme? Pengangkatan topik ini bertujuan agar masyarakat sebagai pembaca bisa lebih menyadari adanya keberagaman gaya hidup oleh masing-masing manusia, dan untuk tidak terlalu terpaku dalam melihat suatu fenomena dari kacamata yang telah ia pakai di hidupnya. Hasil atas pertanyaan-pertanyaan ini diharapkan dapat memberi sudut pandang serta wawasan baru kepada kalangan masyarakat khususnya anak muda di Indonesia mengenai gambaran agama di kehidupan masyarakat modern yang dijalani mahasiswa di 
Jakarta. Sebagai pengingat bahwa dalam penelitian ini akan ditemukan beberapa penjabaran sudut pandang yang unik mengenai agama dan sifatnya sangatlah pribadi dan mungkin akan sedikit kontra dengan masyarakat kebanyakan.

\section{Metode}

Penelitian ini dilakukan dengan pendekatan kualitatif karena membutuhkan banyak perspektif serta penggalian informasi yang mendalam, yang tidak cukup apabila dilakukan dengan pengukuran-pengukuran. Penelitian dilakukan di daerah Ibu Kota DKI Jakarta terhadap mahasiswa yang sedang menempuh pendidikan tinggi di daerah Jakarta, serta berdomisili di Jakarta (Pusat, Utara, dan Timur). Pemilihan informan didasari oleh observasi penulis terhadap latar belakang subjek serta kesesuaian dengan penelitian yang dibuat. Subjek penelitian kunci berjumlah 6 orang dan 1 orang informan pendukung yang dianggap paling tahu mengenai hal yang dibahas. Seluruh informan berasal dari daerah Jakarta, sedang menempuh pendidikan perguruan tinggi di Jakarta, tentunya berstatus sebagai mahasiswa dan pada saat ditulisnya penelitian ini sedang berumur 19-20 tahun, sangat mengikuti perkembangan trend gaya hidup masa kini, dan memiliki banyak lingkaran pergaulan.

Penelitian dilakukan dalam dua babak waktu yaitu 28-30 November 2020 yang digunakan untuk membaca penelitian terdahulu serta untuk memperoleh ide/gambaran arah penelitian yang akan ditulis, dan 1-5 Desember 2020, dimana penulis telah mulai menyusun penelitian dan melakukan wawancara terhadap masing-masing informan yang telah penulis pilih dan percayai. Penelitian ini menggunakan teknik pengumpulan data lewat wawancara terstruktur secara daring (karena pandemi COVID-19) melalui aplikasi pesan WhatsApp, LINE, dan Instagram Direct Message. Teknik wawancara dipilih karena dianggap sebagai cara yang tepat bagi penulis untuk mengumpulkan informasi secara luas dan mendalam. Wawancara juga dianggap memudahkan informan dalam menjawb pertanyaan, karena ia memiliki kebebasan dan tidak terpaku oleh pilihan jawaban tertentu untuk menjabarkan opininya terkait pertanyaan. Sebelumnya peneliti telah menyiapkan pertanyaan apa saja yang akan diajukan, sesuai dengan acuan batasan permasalahan dan kaitan dengan kajian teori penelitian. Wawancara dilakukan lewat beberapa tahapan, yaitu dimulai dari pembukaan (perkenalan dan gambaran singkat topik bahasan), pengajuan pertanyaan, dan penutup.

Tabel 1. Pengembangan Instrumen Penelitian Mengacu Pada Batasan Permasalahan

\begin{tabular}{|c|c|c|}
\hline No & Topik & Muatan \\
\hline 1 & $\begin{array}{l}\text { Posisi agama dalam } \\
\text { kehidupan mahasiswa di } \\
\text { Jakarta. }\end{array}$ & 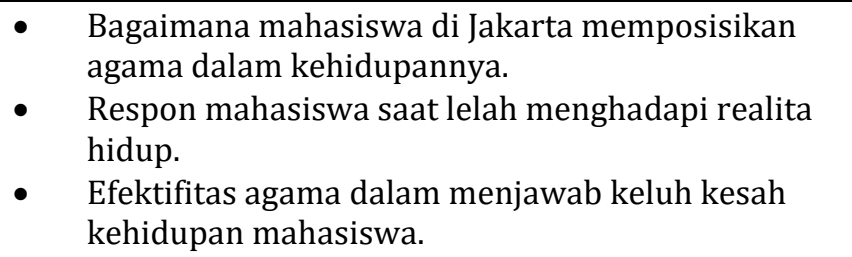 \\
\hline 2 & $\begin{array}{l}\text { Agama yang } \\
\text { berdampingan dengan } \\
\text { kehidupan modern yang } \\
\text { cepat dan kompleks. }\end{array}$ & $\begin{array}{l}\text { - } \quad \text { Relevansi agama di tengah kondisi kehidupan serba } \\
\text { modern menurut pengalaman mahasiswa. }\end{array}$ \\
\hline 3 & $\begin{array}{l}\text { Agama sebagai } \\
\text { penyeimbang maraknya } \\
\text { paham hedonisme dan } \\
\text { individualisme. }\end{array}$ & $\begin{array}{l}\text { - Tindakan yang dilakukan agama dalam menyikapi } \\
\text { hedonisme dan individualisme menurut mahasiswa } \\
\text { di Jakarta. } \\
\text { - Tindakan yang seharusnya dilakukan oleh agama } \\
\text { dalam menghadapi dan menyesuaikan diri dengan } \\
\text { kehidupan modern. }\end{array}$ \\
\hline
\end{tabular}


Data yang dicari mengacu pada beberapa batasan permasalahan penelitilan yang telah disebutkan sebelumnya dalam bentuk transkrip yang berisi jawaban informan atas pertanyaan yang diajukan. Data bersumber pada pihak pertama/informan yang telah dikumpulkan atau biasa disebut data primer, yang diperoleh dari informan yang telah memenuhi kriteria yang penulis sebutkan sebelumnya. Terkait rincian informan akan dijabarkan sebagai berikut:

Data yang telah terkumpul kemudian dilakukan analisa melewati 3 tahapan, yaitu 1) Reduksi Data, yaitu proses pemilihan, fokus perhatian pada proses penyederhanaan, abstraksi, dan transformasi dari kumpulan data kasar yang diperoleh dari catatan di lapangan menjadi data inti yang jelas; 2) Triangulasi, yaitu teknik pengecekan keabsahan data dengan memanfaatkan suatu hal yang lain dalam mengkomparasikan hasil wawancara setiap objek penelitian (Moeloeng, 2004); 3) Penyajian Data, data yang telah dikumpulkan dan diolah akan disajikan secara tersusun, terperinci, serta menyeluruh untuk mencari pola hubungan data, sehingga dapat ditarik kesimpulan dan pengambilan tindakan; dan 4) Penarikan Kesimpulan, untuk menemukan makna, arti, dan penjelasan singkat tentang data yang telah dianalisis sebelumnya.

\section{Hasil dan Pembahasan}

Setiap mahasiswa memiliki cara pandang dan berpikir tersendiri terhadap berbagai hal di kehidupannya, termasuk dalam caranya memposisikan agama di dalam kehidupannya. Mahasiswa di Jakarta sendiri sudah tidak diragukan lagi menerima banyak pengaruh globalisasi dikarenakan peran kota Jakarta itu sendiri sebagai pusat berbagai macam aktivitas kehidupan dan sebagai Ibu Kota Indonesia. Kehidupan di era in, khususnya di kota-kota besar adalah kehidupan yang serba modern dan instan. Masyarakatnya juga dituntut untuk memiliki kompetensi yang baik agar dapat bersaing dengan golongan tertentu. Pergaulan remajanya pun bisa dikatakan selangkah lebih maju daripada yang lainnya dikarenakan arus globalisasi yang lebih besar.

Dalam penelitian ini, penulis menemukan bahwa persepsi atau sudut pandang yang terbentuk oleh mahasiswa ini terbagi menjadi dua sisi, yaitu sisi yang memprioritaskan agama dan yang sebaliknya, berdasarkan kondisi serta pemikiran mahasiswa itu sendiri. Hal ini dapat dilihat dari pendapat informan yang mengutamakan agamanya karena dengan agamalah kehidupan dapat berjalan dengan baik.Apalagi, Indonesia merupakan negara yang berlandaskan ideologi Pancasila, dimana sila pertama sendiri berbunyi "Ketuhanan Yang Maha Esa", yang menunjukan nilai-nilai ketuhanan yang dianut masyarakat Indonesia. Menurut salah satu informan, dengan berlandaskan sila pertama ini, agama atau keperayaan tertentu merupakan kebutuhan wajib masyarakat Indonesia. Di sisi lain, apabila dikaji secara batiniah, agama dijadikan asupan rohani dan nilai-nilai kasih dalam kehidupan. Dengan adanya agama, penganutnya menjadi bisa terhubung dengan Tuhan-nya melalui doa-doa yang telah dibuat sebelumnya.

Berbeda lagi dengan mahasiswa yang tidak memprioritaskan agama dalam kehidupannya, ini disebabkan oleh berbagai hal. Agama hanya dijadikan sebagai identitas dalam kehidupan karena agama dirasakan sebagai hal yang diturunkan oleh orang tua, bukan pilihan masing-masing. Selain itu, berbalikan dengan pendapat sebelumnya, karena Indonesia merupakan negara dengan ideologi Pancasila dimana sila satu berbunyi tentang ketuhanan, agama dijadikan sebuah hal yang wajib. Maka dari itu, untuk diterima dan dianggap wajar oleh 
masyarakat pada umumnya, orang-orang yang tidak memprioritaskan agamanya hanya menjadikan agama sebagai identitas semata agar dipermudah dalam beberapa hal dalam kehidupan, contohnya seperti urusan administratif, keperluan perkawinan, dan sebagainya. Bergesernya esensi agama dalam kasus ini disebabkan oleh perkembangan pemikiran seseorang yang kemudian mengarahkan pada suatu hal yang ia anggap benar.

Adapula mahasiswa yang memang tidak memprioritaskan agama dalam kehidupannya begitu saja. Hal ini terjadi karena kurangnya pemahaman dan penanaman unsur agama dalam kehidupannya sejak ia masih kecil. Hal ini mengindikasikan bahwa keluarga merupakan agen penting dalam menanamkan modal-modal kehidupan seseorang. Keluarga merupakan lingkungan primer seorang manusia tumbuh, maka dari itu kondisi keluarga akan mempengaruhi kehidupan seseorang nantinya. Sementara dalam hal ini, pergaulan yang begitu luas yang dialami oleh mahasiswa di Jakarta ini terlihat tidak terlalu memberi pengaruh akan pemahamannya tentang agama di dalam kehidupannya.

\subsection{Manusia Harus Tetap Berpedoman Pada Agama}

Tidak bisa terelakkan lagi bahwa zaman sudah semakin maju, teknologi berkembang pesat, yang kemudian menawarkan kehidupan yang serba instan dan cepat. Perkembangan ini kemudian juga menimbulkan permasalahan baru. Lahirnya teknologi canggih ini merupakan buah dari pemikiran manusia yang semakin maju pula yang kemudian mempengaruhi seluruh bidang kehidupan, termasuk agama. Agama pada zaman ini hidup di tengah globalisasi menimbulkan tantangan baru.

Menurut mahasiswa sendiri, bukanlah tugas utama institusi agama untuk selalu menyesuaikan diri dengan perkembangan manusia dunia, namun manusia itu sendiri yang harus berpegang teguh pada agama. Agama tidak bisa mengikuti secara menyeluruh perkembangan dunia karena disana terdapat dogma-dogma yang tidak bisa diubah, karena hal tersebut mengehilangkan esensi agama itu sendiri. Contohnya dalam menyikapi paham individualisme dan hedonisme yang bertentangan dengan ajaran agama, seharusnya manusianya itu sendirilah yang memiliki kontrol diri. Memang, institusi agama juga perlu mengadakan dakwah/kotbah/ajakan untuk menghindari paham tersebut sebagai bentuk kepedulian terhadap umat, namun semua tergantung manusia itu sendiri. Agama tetap mengambil tindakan dalam menyikapi perkembangan zaman seperti memunculkan kitab suci digital, ikut berpartisipasi di hari-hari nasional (seperti Hari Batik, Hari Pahlawan, dsb) dengan memodifikasi pakaian umat saat beribadah. Hal tersebut bukanlah semata-mata untuk iseng saja, melainkan agar agama tetap terasa dekat, relevan, dan merakyat di mata masyarakat walau di tengah kondisi kehidupan modern seperti ini. Selama hal tersebut tidak menghilangkan esensi ajaran suatu agama itu sendiri, itu masih tidak masalah.

Manusia dan agama kaitannya tidak pernah lepas. Setiap perkembangan aspek kehidupan di dunia merupakan tantangan baru bagi agama itu sendiri. Globalisasi, paham modern yang bertentangan dengan ajaran agama, dan peradaban manusia yang semakin maju itu sendiri kemudian mempertanyakan apa yang harus dilakukan oleh agama itu sendiri. Jawaban lain ditemukan dalam mempertanyakan ini, dimana manusialah yang seharusnya lebih gencar dalam memeluk dan tetap mematuhi ajaran agama itu sendiri. Seperti saat menyikapi paham modern individualisme dan hedonisme yang bertentangan dengan ajaran agama serta banyak berkembang dan erat kaitannya dengan gaya hidup di kota-kota besar. Hal 
tersebut lebih tergantung kepada manusia, tentang jalan kehidupan mana yang ia mau pilih. Bukan tugas utama atau prioritas agama dalam menyesuaikan diri dengan kemajuan peradaban manusia, karena bila agama yang melakukan hal tersebut secara intens, ini dapat menghilangkan esensi ajaran agama itu sendiri karena di dalam agama terdapat dogma-dogma yang tidak bisa digantikan dan di modifikasi.

\subsection{Agama Masih Digunakan Oleh Mahasiswa Saat Menghadapi Masalah Hidup}

Kehidupan manusia pasti tidak lepas dari masalah. Dalam hal ini mahasiswa berpendapat bahwa hal terbaik saat menghadapi sebuah permasalahan adalah dengan beristirahat sejenak, baik secara mental maupun fisik dari kehidupan yang terus berjalan. Hal tersebut merupakan tindakan pertama mahasiswa saat menghadapi suatu permasalahan. Masalahnya sangat bervariasi, mulai dari yang sederhana seperti merasa lelah mengerjakan tugas kuliah, sampai masalah-masalah yang rumit. Istirahat dibutuhkan agar jiwa dan raga bisa beristirahat dan memikirkan solusi kedepannya. Refleksi diri juga merupakan sesuatu yang penting dalam memahami seberapa pantaskah kita menerima masalah atau memilih meninggalkan permasalahan tersebut. Terdapat beberapa variasi jawaban tentang peran agama dalam hal ini. Agama memang membantu manusia saat tertimpa masalah, namun, cenderung membantu dalam hal rohaniah/batiniah, karena agama tidak terlalu sering memberikan jawaban secara langsung atas problema hidup. Hal ini kemudian menunjukkan bahwa mahasiswa memilih solusi yang konkrit terlebih dahulu, seperti menenangkan diri, refreshing, istirahat, dan sebagainya. Setelah solusi tersebut dirasa cukup, berdoa menjadi solusi selanjutnya sesuai dengan keyakinannya masing-masing dalam meminta berkat dari Tuhan. Biasanya para mahasiswa ini mengajukan rasa syukur terimakasih, perlindungan, dan penguatan diri dalam menghadapi masalah yang sedang dialaminya.

Agama memberi jawaban lewat caranya sendiri yang tidak bisa dipahami oleh manusia karena keterbatasan pemikirannya. Agama memberi ketenangan terhadap jiwa ketika dilanda masalah. Dengan mengingat kembali ajaran agama, manusia kembali diajak untuk lebih bersyukur dengan kehidupan yang ia miliki. Agama memang bukan merupakan jawaban dan andalan utama saat menghadapi suatu permasalahan, namun, agama bisa dijadikan tempat mengadu manusia untuk mewujudkan kelegaan hati, yang nantinya semua keluhan tersebut terjawab dengan sendirinya lewat cara kerja doa yang masih misterius.

Masalah kehidupan bisa menimpa siapa saja. Di tengah-tengah kesibukan dan lika-liku kehidupan mahasiswa, agama masih dijadikan sebagai pendukung kedamaian jiwa. Hal ini menunjukkan bahwa agama masih terasa dekat di kehidupan mahasiswa di Jakarta. Ketika menghadapi masalah kehidupan, mahasiswa memilih untuk beristirahat, baik secara fisik maupun mental. Bisa dengan berdiam diri, istirahat dari social media, refleksi diri. Setelah hal ini dirasa cukup, barulah peran agama muncul sebagai penguatan rasa bersyukur atas kehidupan yang telah diberikan. Walaupun dengan berdoa tidak selalu langsung mendapat jawaban, setidaknya hal tersebut merupakan salah satu faktor pendukung kelegaan dalam hati.

\subsection{Agama Dalam Kehidupan Modern Mahasiswa di Jakarta Dilihat Dari Teori Kritis Jurgen Habermas}

Topik mengenai agama dalam kehidupan modern mahasiswa di Jakarta dapat dianalisis menggunakan teori krits Jurgen Habermas, dimana teori kritis ini pada daarnya menekankan kepada jalinan komunikasi yang sehat antara 2 pihak terkait untuk menghasilkan hubungan 
yang baik pula. Habermas menganggap bahwa masyarakat modern saat ini terlalu berorientasi pada rasionalitas instrumental, yaitu rasionalitas yang cenderung mengarah kepada penggunaannya saja (Viktorahadi, 2017). Berkembangnya orientasi rasonalitas instrumental ini sendiri kemudian berdampak pada kehidupan manusia yang terlalu bergantung kepada teknologi dan unsur kepemerintahan. Habermas membagi masyarakat dengan orientasi tersebut menjadi dua yaitu, 1) tahap teori sosial, dimana manusia berpikir teknokratis dan 2) tahap teori pengetahuan, dimana positivism menguasai pemikiran masyarakat modern. Kedua tahapan ini sangat beresiko mengancam dimensi relfektif dalam kehidupan manusia. Padahal, tanpa adanya dimensi reflektif tersebut dalam kehidupan manusia, Habermas memandang bahwa manusia bisa kehilangan makna hidup.

Berdasarkan persoalan ini, Habermas akhirnya mencetuskan sebuah paradigma baru yang member kesempatan kepada manusia untuk berusaha meraih rasionalitas yang lebih komunikatif. Paradigma ini merupakan wujud etik komunikatif secara universal. Habermas menggunakan paradigma ini dengan pendekatan praksis kehidupan realita manusiia dan subjektivitas. Teorinya ini secara tidak langsung ikut terkait tentang persoalan agama. Agama akan selalu berdampingan dengan kehidupan manusia. Habermas hanya bisa memahami proses evolusi yang terjadi di masyarakat apabila ia memahami peran yang diemban oleh agama itu sendiri.

Disinilah diperlukan teori kritik Habermas terhadap agama kontemporer masa kini. Di zaman yang semakin modern, muncul permasalahan baru yang lebih kompleks pula. Segala kritik, pertimbangan, serta pemikiran diperlukan oleh sebuah ajaran agama untuk menemukan kebenaran dan kesepahaman. Teori kritis berguna sebagai mediasi agama dalam berbahasa dan menyampaikan ajarannya dalam cara yang lebih mudah dimengerti oleh manusia-manusia di zaman ini. Agama harus bisa menyesuaikan diri dengan peradaban manusia yang semakin modern. Kalau tidak dilakukan pendekatan secara kritis, institusi agama cenderung tidak menghargai dunia lagi (Prihatanto, 2007). Begitu pula di sisi lain, dilihat dari pihak dunia, bila agama tidak bisa menyesuaikan diri, maka dunia cenderung menolak ajaran tersebut. Maka dari itu, disinal teori kritik Jurgen Habermas diperlukan untuk membahas persoalan agama di tengah-tengah kehidupan modern mahasiswa di Jakarta.

Zaman ini semakin modern dan serba instan, arus globalisasi semakin kencang terlebih di kota-kota besar, termasuk di Ibu Kota Jakarta yang kemudian berdampak pula pada kehidupan masyarakatnya. Kehidupan modern ini tak bisa dihindari akan memunculkan permasalahan yang baru dan kompleks pula. Segala pertimbangan, kritik, dan pemikiran harus diperhatikna oleh suatu agama dalam menemukan kesepahaman dan kebenaran. Disinilah peran teori kritis yaitu sebagai sarana mediasi antara agama dan masyarakat modern dalam berdialektika dan menyampaikan ajaran agamanya lewat cara yang lebih mudah dipahami oleh masyarakat kita. Contohnya seperti memberikan perumpamaan bukan lagi membandingkan dengan hal-hal magis di luar nalar seperti yang terjadi berabad-abad silam. Namun, dengan menggunakan perbandingan yang sesuai dengan realita masyarakat modern zaman ini. Agama harus bisa menyeimbangkan diri dengan hebatnya arus globalisasi.

Agama tidak bisa terus-terusan dalam posisi keekslusifannya, namun ia harus membaur menjadi lebih dekat dengan realita, merakyat, dan menggandeng masyarakat. Hal ini sudah nampak terjadi di Indonesia sendiri dimana agama juga memodifikasi beberapa hal seperti ikut berpartisipasi dalam hari-hari besar nasional di Indonesia (seperti saat Hari Batik Nasional, 
gereja berpartisipasi dengan menggunakan batik saat beribadah, saat Hari Kemerdekaan Indonesia menambah ornament-ornamen kebangsaan seperti bendera Merah Putih dan kotbah/dakwah yang kembali mengingatkan umatnya tentang jasa pahlawan, dan sebagainya), atau seperti diciptakannya kitab suci digital yang bertujuan untuk memudahkan manusia modern mengakses kitabnya. Dibuatnya kitab suci digital ini mengingat bahwa hampir semua manusia yang tinggal di zaman ini pasti dekat dengan gawai. Agama dalam hal ini mencoba membaur dengan mengetahui bahwa manusia zaman ini tidak bisa lepas dari gawai, lalu melakukan pengembangan sehingga manusia tidak perlu lagi berkutat membawa kitab suci kemana-mana, namun cukup dengan mengakses aplikasi lewat gawainya.

Hal-hal tersebut telah menunjukkan bahwa agama juga terus berupaya berdampingan dengan realita kehidupan manusia. Dengan menggunakan teori kritik Jurgen Habermas ini terhadap agama di kehidupan modern mahasiswa di Jakarta ingin menunjukkan bahwa kelancaran komunikasi dan ekspresi antara kedua belah pihak (agama dan manusia) agama tetap bisa mengambil partisipasi besar dalam kehidupan manusia modern. Penggunaan cara lama dan perumpamaan yang terlalu mengandai-andai bukanlah lagi cara agama meneruskan tugasnya untuk meneruskan ajarannya di tengah-tengah masyarakat modern (Viktorhadi, 2017). Agama membutuhkan terobosan baru dalam merombak cara penyampaian ajarannya, karena masyarakat modern membutuhkan agama yang hadir, dekat, dan relevan di kehidupannya.

\section{Simpulan}

Mengangkat topik mengenai agama di tengah kehidupan modern bagi mahasiswa di Jakarta, penulis menerima jawaban serta sudut pandang yang unik. Hal ini membuktikan bahwa masing-masing manusia memiliki cara hidup dan cara pandangnya tersendiri, dan merupakan sebuah hal baik bagi kita apabila mau saling menghargai jalan hidup orang lain. Dari hasil penelitian yang telah dianalisis maka penulis akan memberi beberapa kesimpulan atas penelitian ini, bahwa: (1) Terdapat berbagai macam jawaban unik dari mahasiswa di Jakarta terhadap bagaimana cara para mahasiswa ini melihat agama di dalam kehidupan mereka. Peneliti menyimpulkan bahwa perspektif ini terbagi menjadi dua yaitu memprioritaskan agama dan yang tidak memperioritaskan agamanya. Hal ini terjadi didasari oleh kondisi masing-masing mahasiswa terkait. (2) Adapun untuk menjalin kehidupan yang seimbang, antara manusia dan agama itu sendiri harus saling menyeimbangkan diri. Manusia harus tetap berpedoman kepada agama, apalagi di Indonesia yang berlandaskan ideologi Pancasila. Dari pihak agama pun pula harus melakukan penyesuaian dengan perkembangan kehidupan manusia. Melakukan penyesuaian bukanlah hal yang terlarang, selama hal tersebut tidak menggeser makna/esensi, serta dogma agama tersebut. (3) Dalam mengatasi permasalahan hidup, mahasiswa di Jakarta lebih mengandalkan solusi nyata seperti beristirahat, refleksi diri, serta berupaya menemukan jalan keluar secara logis. Namun, agama juga tetap dijadikan antidot atas beban hidup secara rohani, seperti memberi ketenangan lewat lantunan doa-doa yang memunculkan kelegaan dalam hati. Agama memberi rasa syukur atas kehidupan yang telah diberikan ini. (4) Paparan tersebut sejalan dengan pemikiran Habermas atas teori kritisnya dalam menanggapi keberadaan agama di tengah kehidupan modern ini. Habermas khawatir manusia terlalu bersikap rasional, sehingga ia lupa untuk melihat dimensi reflektif di hidupnya. Agama dan manusia harus saling menjalin komunikasi yang sehat dan memudahkan satu sama lain agar dapat saling berjalan beriringan. Apa yang diinginkan oleh manusia zaman ini, apa yang agama inginkan, dan bagaimana caranya agar satu tujuan ini dapat tercapai tanpa merugikan kedua belah pihak. Contoh nyatanya ketika pada zaman ini, 
manusia modern tidak lagi memerlukan perumpamaan dan bahasa yang mengandai-andai khas agama, namun, manusia modern membutuhkan agama yang hadir, dekat, dan selalu relevan dengan kehidupannya sehari-hari. Tidak dapat dipungkiri kondisi masyarakat abad ke 20 sangat berbeda dengan masyarakat di abad sebelumnya, khususnya abad pertengahan ketika agama dianggap sangat ekslusif dan apapun yang dikatakan pihak keagamaan adalah benar, yang kemudian malah membawa malapetaka bagi masyarakat di kala itu, karena banyak petinggi agama yang menyalahgunakan kekuasaannya. Kembali kepada penyederhanaan jalur penyampaian agama terhadap manusia modern, tentu tidak akan menggeser esensi dogma agama, hanya butuh penyederhanaan dan penyesuaian cara penyampaian ajarannya. Komunikasi dan hubungan yang sehat antar kedua pihak pasti akhirnya menemukan titik temu yang baik kedepannya.

\section{Daftar Rujukan}

Joan Hesti Gita Purwasih, Yustinah Eka Janah, Faqih Rizki Gumilar, dan Sri Muhammad Kusumantoro. (2018). Ensiklopedia Sosiologi Kelompok Sosial. Klaten: Cempaka Putih.

Nasrullah, Adon. (2015). Agama dan Konflik Sosial, cetakan pertama. Bandung: Pustaka Setia.

Al-Quran Terjemahan. (2015). Departemen Agama RI. Bandung: CV Darus Sunnah.

Alkitab. (2010). Jakarta: Lembaga Alkitab Indonesia.

Ishomuddin. (2002). Pengantar Sosiologi Agama. Jakarta: Ghalia Indonesia.

Daradjat, Zakiyah. (2005). Ilmu Jiwa Agama. Jakarta: Bulan Bintang.

Dadang Kahmad. (2002). Sosiologi Agama. Bandung: PT. Remaja Rosdakarya.

Prihatanto, P. (2007). Agama, Modernisasi, dan Teori Kritis: Sebuah Potret Pertautan. Unisia, 30(64), 175-182.

Sari, D. A. (2019). Makna Agama dalam Kehidupan Modern. Cakrawala: Jurnal Studi Islam, 14(1), 16-23.

Dasar, J. P. (2015). Dampak Pengaruh Globalisasi Bagi Kehidupan Bangsa Indonesia. Jurnal Pesona Dasar, 3(3), $1-14$.

Anis, M. (2013). Spiritualitas di Tengah Modernitas Perkotaan. Jurnal Bayan, II(4), 1-15.

Hamdi, A. Z. (2013). Agama di Tengah Jaring-jaring Dunia Modern. Religió: Jurnal Studi Agama-Agama, 3(2).

Viktorahadi, B. (2017). Kritik Jürgen Habermas Terhadap Peran Dan Fungsi Agama Dalam. Theologia, 28(2), 273-298.

Fatimah, S. (2013). Hubungan antara Kontrol Diri dengan Kecenderungan Gaya Hidup Hedonis pada Mahasiswi di Surakarta (Doctoral dissertation, Universitas Muhammadiyah Surakarta).

Syarifah, L. (2014). Konsep stres pada masyarakat modern dan upaya penyembuhannya menurut Ishaq Husaini Kuhsari dan Mustamir (perspektif bimbingan konseling Islam) (Doctoral dissertation, UIN Walisongo).

Creswell, J. W., Hanson, W. E., Clark Plano, V. L., \& Morales, A. (2007). Qualitative research designs: Selection and implementation. The counseling psychologist, 35(2), 236-264.

https://medium.com/@tyassiolimbona/sikap-individualisme-3e1f6e06de11

http://kebudayaan.kemdikbud.go.id/muspres/museum-dan-masyarakat-modern/

http://binus.ac.id/charachter-building/pancasila/page/8

https://www.islampos.com/hakikat-kehidupa-dunia-142379/ 